\title{
Humanistic Soft Skills Learning For Generating Professional Teacher Performance
}

\author{
Siti Hamidah \\ Department Food and Fashion Education \\ Yogyakarta State University, Yogyakarta, INDONESIA \\ hamidah_siti66@yahoo.com
}

\begin{abstract}
Teachers are profesional workers. It means being a teacher is encouragement of soul through learning processes with standard quality. Mastery soft skills are a necessity also demand. Mentioned in the Constitution of Teachers and Lecturers, there are four pillars of teacher competence as professional. Soft skills which support mastery of competence in personality and social that impact on teacher professionalism confirmation. This paper intended to describe development of humanistic soft skill learning model that enables the emergence of mastery soft skills naturally. This model can be applied to pre-employ teacher education that provides space for the emergence of dynamic ability to interpret every learning experience as part of a formation of teacher professionalism. The impact of this model is expected with presence of teacher who is able to provide a sense of justice, has a good sense of humor, being fun and vibrant person, responsiveness to change, and ready to learn. This model requires lecturer to improve and develop their soft skills effectively through consultation and coaching.
\end{abstract}

Index Terms - soft skill learning, humanistic, professional teacher.

\section{Introduction}

People choose to be a vocational teacher because of passion, beside self-interest and talent. This power is basic fundamental to make his self as a teacher who is not only capable of teaching, but also has commendable behavior that gives contribution to performance of profession as a professional teacher. The constitution about teacher and lecturer mention that teacher should show the performance of four main pillars, there are pedagogic, personality, social, and professionalism. PPG (Pendidikan Profesi Gurul Teacher Profession Education) program is a hope for all parties to emerge teachers who not only merely profession as a teacher, but also can show professional teacher performance, and four main pillars can materialize in balanced and integrated manner.

Suyanto [1] emphasizes three important requirements for preparing PPG program which can produce professional teacher, there are: curriculum, learning environment, and lecturer. The Curriculum will answer about the objectives to be accomplished, the experiences to be given, organizing of learning, and selected evaluation to measure achievement of the objectives. Learning environment will answer about learning climate, managing condition of surrounding environment to contribute the strengthening of professional teaching process. Lecturer contributes to emergence the main behavior, there are become competent person, become role model, has a vision, and many other excellent behavior. LPTK (Lembaga Pendidikan Tenaga Kependidikan/ Institute of Teacher's Education) as an institution appointed by government, has the responsibility to organize teacher education programs that combine teaching skills, pedagogic theory, and professional skills for supporting emergence of four pillars competence of teacher.

Being a professional teacher still has some constraints, such as: 1) teacher education quality, 2) books/ learning sources [2], 3) teacher inability to perform learning process at school [3]. Hence, teachers participant as input of PPG program should be addressed with strictly teacher selection, and learning is managed properly to integrate soft skills with professional performance. Why should soft skills? Soft skills are: (1) essential device that contribute to foster selfpotential, (2) the power to change, (3) drive all efforts, and (4) distinguished between one teacher and another [4-7].

One definition: soft skills refer to ability to self motivate, use initiative, have an understanding in what should be done and can be done well, can overcome the problems that suddenly emerged, and keep continue to work if the problems still unresolved [8]. Soft skills are skills that enable someone to reach his potential and use his knowledge beneficially and then integrated into his life. It is believed that teachers with sufficient mastery of soft skills will get better in their professional performance.

Teacher is like manager who requires three skills: technical, human, and conceptual [9]. Technical skills are related to proficiency over the work, such as making learning preparation, and determining time allocations for each meeting. Humans skills are interpersonal skills to be able to manage a group of people or interact with other people. For example, builds cooperation between teachers, motivating group members, and builds effective communication. Conceptual skills are visioning and planning skill that needed by managers, for example, make a decision and predicting.

Various studies in other countries shows, in order to make the workers do their job and develop career in any level, they not only mastering hard skills, but also soft skills that is the most important [7,10]. As the candidate of vocational teacher who will teach in SMK (Sekolah Menengah Kejuruan/ Vocational High School), they must have adequate qualifications including soft skills. How is the learning process to aggregate that soft skills? This paper will elaborate humanistic learning model that give space for the emergence of integrated soft skills.

\section{Method}

This paper was developed based on research using sample vocational high school students in catering service study program. This study is development research according to Borg and Gall [11]. R\&D (Research and Development) approach in the field of education [11] used ten steps to be followed, consist of: (1) research and collecting information, (2) planning, (3) develop preliminary form of product, (4) preliminary field testing, 
(5) main product revision, (6) main field testing, (7) operational product revision, (8) operational field testing, (9) final product revision, (10) dissemination and implementation. Research has resulted effective model to develop soft skills sustainability. In their work, student become efficient, systematic, and purposeful [12].

\section{Result and discussion}

\section{A. Learning in pedagogy and andragogy}

The prospective vocational teachers are mature persons who has adequate learning experiences. They matured psychologically, have need of learning, and desire to develop themselves. They graduated from undergraduate major education and D (Diploma) IV major non-education who possess talent, interest, and passion to become a teacher. During pre-service education through PPG Program, prospective teacher will get learning experiences include PPL (Program Pengalaman Lapangan/ Field Experience Program) for one semester.

As an adult, they needs different learning pattern. Teaching and learning strategies are needed for fostering their existence, self-awareness, and capable of using his potential for the sake of learning progress. There is internalization process through learning mechanism which self-determined, using learning experiences effectively and meaningfully.

In pedagogy perspective, learning is coaching, with assumption that students still lack experience, but andragogy gives more learning flexibility to students. Pedagogy is centered on content. The role of lecturer is dominant in determining which, when, and how content should be learned. Andragogy is centered on students. They determine which, when, and how content should be learned. Reference [13] argued that pedagogy are seen to have a subjectcentered orientation to learning and those preferring andragogy a life-centered, task centered or problem-centered orientation to learning [13].

There are some provisions of soft skills learning with andragogy, such as: (1) involving student while planning and evaluation as endeavor to bring self-concept and motivation, (2) using experiences as basis for learning activities. Students utilize experience as a learning medium, bring a willingness to self-improvement, and not make the same mistakes, (3) using subject or content that related to needs of job and personal life. Readiness to learn will be getting better while the subject matter has relevance to the needs of the students.

Those provisions are in line with andragogy principles: (1) when someone getting adult, he can direct himself, (2) adult has gathered learning sources, (3) adult ready when he needs something to know, (4) adult tend to less focus in subjects, but more focus on problems, (5) the strongest motivator is internally [14]. Therefore, whether using pedagogy pattern or andragogy pattern or combination both of them, it is related to consideration about learning context, learning activity, and the needs of teaching and learning.

Curriculum of PPG's Program is designed to meet seven level in KKNI (Indonesian National Qualification Framework). In the appendix of Decree of the President of Republic of Indonesia number 8 in 2012 noted that PPG program graduate : (1) able to plan and manage resources under responsibility, and evaluate his work comprehensively by utilizing science, technology, and/or art to produce steps of developing organizational strategies, (2) able to solve science, technology, and/or art problems in his scientific field through monodiscipliner approach, (3) able to conduct research and take strategic decisions with accountability and responsibility for all aspects under responsibility of his expertise.

The implementation of KKNI seven level associated with main duties of vocational teacher as education personnel : plan the learning process, doing the learning, assess the learning outcome, coach and train student [15]. By observing requirement of teacher competencies, PPG Program learning uses andragogy pattern more than pedagogy but still uses pedagogy. The teacher candidates appreciated learning experiences during studying in undergraduate major education or D IV major non education, and more mature with mature learning experience. In andragogy approach, students learn how to learn, able to create network independently among fields of study in SMK, learn to use thematic patterns, create learning with scientific approach, and many more. Learning becomes more meaningful when student directly involved in concept implementation or provision activities. Prospective teachers will be involved in planning and applying of assessment format of curriculum 2013. Learning experiences can help teacher candidates while working using curriculum 2013 so they can drive students toward learning that foster learning performance.

\section{B. Humanistic Soft Skill Learning}

Every job including educator, need soft skills. Soft skills help working in the workplace and career development. Therefore, strengthening soft skills that fostered is necessary in the learning process. Soft skills training improves individual potential, support more flexible worker, encourage positive attitude to more adaptive, capable to handle a change in work demand and more competitive [16]. Soft skills require learning strategies that enable interpretation process and appearing the internalization process sustainability, through internal motivation mechanism. The performance of soft skills during learning process will ensure emergence of integrated soft skills and contribute to the work of teachers.

Some difficulties arise when apply soft skills as a learning target, such as how to : define it, teach it, and assess the achievement [17]. Soft skills as a learning target should be clear in soft skills behavior. It means that soft skills, not only just a concept, but also can be described well. While applying integrated learning model, soft skills will attach in hard skill behavior.

Similarly, teaching soft skills requires strategy dominated by student activities, such as : a) modeling, playing roles like micro-teaching, b) portofolio by gathering documentation of task performance either theory or practice, c) reflection by using past experiences to reinforce soft skills behavior when learning, or contemplate the needs in the workplace, d) cooperative learning involves team work in completing tasks, or fostering professional performance of they who are teacher candidate by establishing cooperation between SMK and university that appointed by LPTK, e) simulation through real life learning like PPL or industrial practice or learning practice about food service. Students 
involved in simulation as a student and teacher candidate in theory and practice, as a chef who works at hotel's kitchen, as a food service manager with consumers from their own friends, or as worker in campus cafeteria. Likewise, the assessment requires valid and reliable techniques and instrument that able to measure soft skills performance. The involvement of students who are teacher candidates in assessment activities will ensure improvement of soft skills performance. Reference [12] used assessment instrument: reflection, observation, and self-expression. Hopefully, humanistic approach can solve the problems like defining, teaching, and evaluating soft skills during learning.

The humanistic approach chosen because it has in line perspective with andragogy concept. This approach views the teacher candidates who has self-esteem, and can improve their quality by using their abilities. Teacher candidates enable to develop self-potency and self concept through selfdiscovery process, also put them as human dignity.

Associated with PPG program, humanistic approach is chosen because humanistic learning more emphasize in main value learning, form awareness, shape personality of teacher candidates, form positive attitude toward work, shape sensitivity to demand and change at work, and able to analyze change and demand at work. As a figure in humansitic, Carl Rogers [18] emphasized the importance of self-actualization as part of forming personality. Therefore, it is important to emphasize harmonious relationship between ideal self aspect and environment. It is the result of interaction between individual and environment. Environment is some experiences to establish positive side of individual. Soft skills learning experiences that conducted sustainability will enrich positive self concept. Soft skill learning is affective learning that teaches about the values and the main of work behavior for supporting personality and social competences. Learning soft skills by the humanistic approach will automatically strengthen the main behaviors of teacher, such as : being able to provide the sense of justice, having a good sense of humor, being fun and vibrant person, responsiveness to change, and ready to learn.

The humanistic approach enables teacher candidates to assign developed soft skills, formulate an operational definition of selected soft skills that related to learning context, design learning strategies based on teaching scenario, and conduct evaluation independently.

Several points should get attention when lecturers apply humanistic approach are: (1) learning experiences should be managed properly to grow internalization sustainably of soft skills values, (2) individual involves roundly so he can develop the structure of soft skills, and enrich the understanding, (3) packed in delight learning, causing no pressure, and able to drive internal motivation, (4) appreciate past experiences and driven as personal property, (5) encourage to learn and respect individual differences, or to appreciate potencies or advantages and disadvantages.

\section{The Mechanism of Humanistic Soft Skill Learning}

What sort of humanistic soft skill learning? Learning soft skills are designed to remain directed at the established instructional design. Learning soft skills will succeed and affect on self-improvement while subject learning take an active role on study design, implementation, and selfevaluation. This process can occur when learning ability is raised as learning all the time, real life experiences using a variety of learning strategies [19][20][21]. Self-reliant learning will be the main thing, but it is not interpreted to omit learning without direction. Learning is managed by interaction pattern, inductive, emphasizing on process, and students learning. Learning will be meaningful when attached with learning object or hard skills.

The mechanism of humanistic soft skill learning is started from planning, implementation, and evaluation. The planning of learning [12] consists of planning for lecturers and students. Planning for lecturers covering activities: (1) lecturer set the topics with containing soft skills. This topic includes basic competencies which is integrated between hard skills and soft skills. This topic can be developed from indicators or work or activities associated with the context. (2) Lecturer determine performance indicator for every topic. Indicator made regarding to integration between hard skills and soft skills. Lecturer also determine appropriate learning strategies while considering provision of PPG learning, include workshop patterns. (3) Lecturer determine learning support infrastructure, and (4) design an evaluation which is done. Soft skills will be effective when evaluated continuously.

Planning for students covering activities : (1) students study soft skills integrated based on lecturer explanation so they can determine soft skill that will be trained and associated with hard skills. Students can enrich the understanding of soft skills independently by using various sources of information. For example, finding concept for each soft skill that will be practiced, implement the soft skill in many learning contexts and others. This activity is important, because soft skills are part of competence that enriched by knowledge and understanding about object skills. Proficiency of soft skills appear on performance and improved through accelerating knowledge and work experiences [12]. It is shown in figure 1. (2) Based on those studies, students who are teacher candidate design the chosen soft skills behavior and learning activities. An example of soft skills behavior is student has the responsibility to design interesting display. An example of learning activity of soft skills is students can choose display earnestly, design communicative and creative display, and design attractive display. (3) Based on the plan of learning activities, the teacher candidates makes learning contract. This contract as a commitment over learning activities that soft skills chosen. Student is an mature persons who appreciated his potency and respected his dignity, so the contract as a form humanizing human.

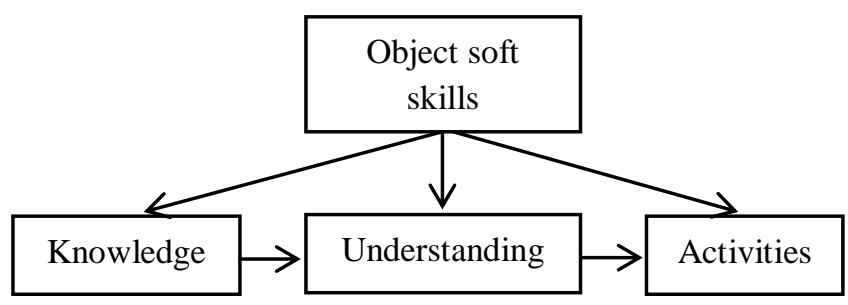

Fig. 1. The relationship between object skills and three element of skills [22]

\section{The Implementation of Humanistic Soft Skill Learning}


There are two important things that should be noted in implementation of humanistic soft skill learning. First, design learning environment that enables the development of integrated soft skills with hard skills. Selected integration pattern are: fragmented, connected, immersed [23]. Fragmented integration pattern focused on discipline. Each discipline stands alone, and taught by different lecturers. Lecturers can prepare more professional discipline, broader, and deeper. Connected model use the relationship of each subject, and teaching material. This connection occurs between topic, concept and concept, skills with each other, also with work both current and future, or perhaps with ideas in the following semester. Students will gain greater understanding, and then occurs internalization process and meaning of learning. Immersed model assures independent learning. This model occurs internalization processes of various material of subject study to the subjects which are studied by students. There is learning independence to do immersed process. This process makes students can exceed and become expert, so the integration is naturally happening. It will encourage students to expand individually, make various material, bring together all the skills, concepts, and work attitude, also this connection will occurs automatically. Lecturers team facilitates this process by estimating its synthesis.

Integration pattern of soft skills into curriculum has shown its effectiveness. Effection of soft skills integration into business curriculum can help student to obtain and retain employment [24]. Through integration, the teacher candidates can work earnestly, foster internal motivation, appear initiatives and creativity independently.

The second, the roles of lecturer are motivate and facilitate the emergence concept for each soft skills and their meaning during learning. Motivation and facilities that provided by lecturer encourage soft skill behavior as a form of habituation. The lecturer can give reinforcement or punishment for reprimanding. The lecturer also should contribute effectively to foster and develop soft skill sustainably through consultation and coaching. This role tends to direct, provide a way out, and facilitate learning to develop soft skills in order to give meaning to the development of work performance. Students remain a major determinant of learning success.

\section{E. Evaluation of Soft Skills}

Evaluation is intended to assess soft skill performance. Soft skills attach with hard skills, then evaluation done through [12] observation, self-evaluation via rubrics that can be done three times (at the beginning, middle, end), and terminated with self-expression. Through this methods, students are aware more about self position and emerge the mechanism of self-improvement through internal motivation. The evaluation activity refers to results of study by Hamidah [12] that shown the effectiveness of soft skills proficiency during learning.

Integrated evaluation procedure is effective for measuring mastery of integrated soft skills. The tools that can be used are checklist, rubrics, journal, portfolio, and reflection [24]. The implementation mechanism of humanistic soft skill learning is presented in Figure 2.
Fig. 2. Implementation mechanism of humanistic soft skill learning

\section{Conclusions}

Humanistic soft skill learning are an option for students who are candidates of vocational teachers because this perspective contributes to strengthening professional characters of vocational teacher. During pre-service education through PPG program, the study conducted in delighted and excited of andagogy pattern. The teacher candidates involve effectively in learning plan, implementation, and evaluation. Learning is managed properly to foster internalization of sustainable soft skills values. The teacher candidates involve effectively by defining trained soft skills, formulating learning activities of soft skills that related to context, implementing learning activites through learning experiences that designed by lecturer, and evaluating independently. Lecturer gives sustainable guidance and coaching as a part of habituation effort, and internalization of soft skills values. The development of learning model of humanistic soft skills can be applied to many kinds of learning content.

\section{References}

[1] Suyanto, Peran Pendidikan Profesi Guru (PPG) dalam Menyiapkan Tenaga Kependidikan yang Profesional dan Berkarakter. Direktorat Jendral Manajemen Pendidikan dasar dan Menengah. Kementerian Pendidikan Nasional, 2012.

[2] Elfendri, J. Rumengan, M. B. Wello, P. Tobing, F. Yanti, Zein, E. Eriyani, and R. Indra, Soft Skills untuk Pendidik. Indonesia. Pranita Offset, 2010.

[3] H. Darmadi, "Membangun kinerja guru dan mutu pendidikan". [Online] Available: http://hamiddarmadi.blogspot.com/2012/09/membangun-kinerja-gurudan-mutu.html.

[4] P. Klaus, J. Rohman, and M. Hamaker, The hard Truth about Soft Skills. NY: HarperCollins e-book, 2007.

[5] L. Leung, How teached can broaden their soft skills. New York: IT Career and Training Alert newsletter, 2008.

[6] K. Lynch, "Collaborative work skillls for begining IS professional". [Online] Available: http://proceding.informingscince.org/insite/066lynch.pdf.

[7] G. Sharma, and P. Sharma, "Importance of Soft skills development in 21st century Curriculum". International Journal of Education and Allied Sciences, Vol. 2, No. 2, pp. 39-44, 2010.

[8] I. Grugulis, Skill, Training. and human resource development. Critical texts. England: Palgrave Macmilan.

[9] M. R. Weber, D. A. Finley, Crawford, A. Crawford, and D. Rivera, Jr., "An exploratory study identifying soft skill competencies in entrylevel managers". International Journal of Education and Allied Science, Vol. 2, pp. 39-44, 2010. 
[10] S. Deepa., and M. Seth, "Do soft skills matter?- Implication for educators based on recruiters' perspective". The IUP Journal of Soft Skills, Vol. 7, pp. 7-20, 2013.

[11] R. W. Borg, and D. M, Gall, Educational research. New York: Logman inc, 1983.

[12] S. Hamidah, "Pengembangan Model Pembelajaran Soft Skills Terintegrasi bagi siswa SMK Program Studi Tata Boga Kompetensi Keahlian Jasa Boga". Doctoral Dissertation, 2011.

[13] B. L.,Delahaye, D. C. Limerick, and G. Hearn, "The relationship between andragogical and pedagogical orientations and the implications for adult learning". Adult Education Quarterly, Vol. 44, pp. 187-200, 1994.

[14] H. Fry, S. Keteeridge, and S. Marshall, Handbook teaching and learning strategy: Peningkatan mutu pendidikan di perguruan Tinggi, Translated by Ahmad Asnawi, Pekanbaru: Zanafa Publishing, 2013.

[15] Anonim, Undang - undang guru dan dosen (UU RI no 14 Th 2005), Jakarta:Sinar Grafika.

[16] E. M. S. Rani, "Need and importance of soft skills in student", Journal of Literature and MediaStudies, Vol. 2, pp. 1-6, 2010.

[17] Policy statement 67. This we believe about teaching the soft skills: Human relations, self - manajement, and workplace enhancement. [Online] Available: http://cache.search-yahooht2.akadns.net/search/cache?ei=UTF-8\&p.

[18] C. H. Patterson, "Foundation for theory of instruction and educational psychology". [Online] Available: www.sageofasheville.com/pub_downloads/CARL_ROGERS_AND_ HUMANISTIC_EDUCATION.pdf.

[19] J. R. Bowles, Does the inclusion of "soft skill" training in a technical workforce development program effect student motivation? Middlesex Community College.

[20] B. Woodward, P. Sendall, and W. Ceccuci. Integreting soft skills competencies through project-based learning across the information system curriculum. Washington DC: Proc ISECON, 2009.

[21] E. S. Hovis, "Instructional design model for courseware". [Online] Available www.Skillsoft.com/infarenter/ whitepepers/ documents/ IDmodel_peper_2007.pdf.

[22] J. A. S. Simpson, The measurement and recognition of soft skills developing a common standard? Produced in partnership with the University of Surrey, 2006.

[23] Forgarty, R. How to integrate the curricula. Illinois : IRI/Skylight Publishing, Inc, 1991.

[24] G. N. Mitchell, Essential Soft Skills For Success In Twenty-First Century Workforce as Perceived. East Elsenhower Parkway: Alabama Business/Marketing Educators, 2008. 